\title{
Genetic diversity of Tambaqui (Teleostei - Characidae) broodstocks from Northern region of Brazil using microsatellite markers
}

\section{Diversidade genética de estoque de Tambaqui (Teleostei - Characidae) da região Norte do Brasil usando marcadores microssatélites}

\author{
Angela Maria Urrea-Rojas ${ }^{1}$; Felipe Pinheiro de Souza ${ }^{1}$; Ed Christian Suzuki de \\ Lima $^{1}$; Andrei Lincoln Yamachita ${ }^{2}$; Victor César Freitas Pandolfi; ; Sara Mataroli \\ de Godoy $;$; Ricardo Pereira Ribeiro5; Jayme Aparecido Povh ${ }^{6}$; Ulisses de Pádua \\ Pereira $^{7}$; Nelson Mauricio Lopera-Barrero ${ }^{8 *}$
}

\section{Highlights:}

Molecular study in fish farmed Tambaqui.

Moderate genetic differentiation between stocks.

Positive $\mathrm{F}_{\mathrm{IS}}$ (inbreeding coefficient) in three stocks.

\begin{abstract}
The Amazonian fish Tambaqui (Colossoma macropomum) is the most common native species in Brazil. This species has the highest production rate in the Northern region, especially in the State of Rondônia. The genetic evaluation of Tambaqui is an extremely important to increase productivity in fish farms or improve the adaptability in restocking natural populations. The objective of this study was to evaluate the genetic diversity of three Tambaqui broodstocks in Rondônia, Brazil. Six microsatellite markers were used to analyze a total of 89 breeders collected from three fish farms located in Ji-Paraná (JP), Ouro Preto do Oeste (OP) and Presidente Médici (PM). A total of 37 alleles between 140 and 310 bp were found, including the presence of exclusive and low frequency alleles in the three broodstocks. The average values of observed heterozygosity ranged from 0.404 (PM) to 0.499 (JP). The $\mathrm{F}_{\text {IS }}$ coefficient values were positive for the three broodstocks, demonstrating a deficit of heterozygotes. The Molecular Variance Analysis (AMOVA) showed greater variation within the stocks than between them. The genetic differentiation was moderate and significant between the stocks, with higher differentiation between JP x PM and lower between OP x PM. The Bayesian analysis designated an optimal value of K $=3$ groupings. Although there is moderate genetic diversity between broodstocks, the high $\mathrm{F}_{\text {IS }}$ indicates a possible decline of diversity in the next generations, and therefore, the incorporation of new breeders is suggested to increase the genetic diversity in the three stocks.
\end{abstract}

Key words: Colossoma macropomum. Conservation. Genetic variability. Microsatellites. SSR.

\footnotetext{
1 Discentes do Programa de Pós-Graduação em Ciência Animal, Universidade Estadual de Londrina, UEL, Londrina, PR, Brasil. E-mail: amur03013@gmail.com; felipeps1991@gmail.com; edchris7@hotmail.com

2 Discente do Programa de Pós-Graduação em Biotecnologia, UEL, Londrina, PR, Brasil. E-mail: andreilincoln16@gmail.com

3 M.e em Ciência Animal, UEL, Londrina, PR, Brasil. E-mail: vcfpand@gmail.com

4 Pós-Doutoranda do Programa de Pós-Graduação em Genética e Biologia Molecular, UEL, Londrina, PR, Brasil. E-mail: godoy. sm@hotmail.com

5 Prof. Dr., Curso de Zootecnia, Universidade Estadual de Maringá, UEM, Maringá, PR, Brasil. E-mail: rpribeiro@uem.br

6 Prof. Dr., Faculdade de Medicina Veterinária e Zootecnia, Universidade Federal de Mato Grosso do Sul, UFMS, Campo Grande, MS, Brasil. E-mail: jayme.povh@ufms.br

7 Prof. Dr., Departamento de Medicina Veterinária Preventiva, UEL, Londrina, PR, Brasil. E-mail: upaduapereira@uel.br

Prof. Dr., Departamento de Zootecnia, UEL, Londrina, PR, Brasil. E-mail: nmlopera@uel.br

Author for correspondence
} 


\section{Resumo}

O peixe amazônico Tambaqui (Colossoma macropomum) é a espécie nativa mais produzida no Brasil. Esta espécie é a mais criada na região Norte, principalmente no Estado de Rondônia. A avaliação genética de Tambaqui é extremamente importante para aumentar a produtividade nas pisciculturas ou melhorar a adaptabilidade no repovoamento de populações naturais. O objetivo deste estudo foi avaliar a diversidade genética de três estoques de Tambaqui em Rondônia, Brasil. Seis marcadores microssatélites foram utilizados para analisar um total de 89 reprodutores coletados em três pisciculturas localizadas em Ji-Paraná (JP), Ouro Preto do Oeste (OP) e Presidente Médici (PM). Foram encontrados 37 alelos entre 140 e $310 \mathrm{pb}$, incluindo a presença de alelos exclusivos e de baixa frequência nas três ninhadas. Os valores médios de heterozigosidade observada variaram de 0,404 (PM) a 0,499 (JP). Os valores do coeficiente de $\mathrm{F}_{\text {IS }}$ foram positivos para as três ninhadas, demonstrando déficit de heterozigotos. A Análise de Variância Molecular (AMOVA) mostrou maior variação dentro dos estoques do que entre eles. A diferenciação genética foi moderada e significativa entre os estoques, com maior diferenciação entre JP x PM e menor entre OP x PM. A análise bayesiana designou um valor ótimo de $\mathrm{K}=3$ agrupamentos. Embora exista uma diversidade genética moderada entre os filhotes, o alto SIF indica um possível declínio da diversidade nas próximas gerações e, portanto, sugere-se a incorporação de novos criadores para aumentar a diversidade genética nos três estoques.

Palavra-chave: Colossoma macropomum. Conservação. Microssatélites. SSR. Variabilidade genética.

\section{Introduction}

World aquaculture fish production in 2018 reached 82.1 million tons, which an increase of 2.6 million tons over that of the year 2016 (Food and Agriculture Organization [FAO], 2020). Following the same trend, in Brazil, in 2019 the production was 758 thousand tons, representing an increase of $4.9 \%$ in relation to the previous year (Peixe BR, 2020). The production of native fish in Brazil represented about $38 \%$ (287,930 tons) of the total production, with emphasis on the species of Tambaqui (Colossoma macropomum) (Peixe BR, 2020). This species has the highest production rate in the Northern region of Brazil and is the most produced native species in the country, with the State of Rondônia being its main producer with 69 thousand tons (Peixe BR, 2020).

Colossoma macropomum is a species belonging to the order Characiformes, family Characidae, and is naturally present on the banks of the Amazon and Orinoco rivers. It is a very important fish due to its ease of cultivation, high productivity, easy reproduction and high commercial value (AraujoLima \& Goulding, 1997; Costa, Freitas, Gomes, Carneiro, \& Martins, 2016). Its production is currently widespread, spanning several fish farms in the Southeast, Central West and Northeast regions of Brazil. Despite its commercial and cultural importance, its populations have been reported to be declining in the basins where it naturally occurs, with extractives being one of the main causes (Moraes et al., 2017).

Due to population reduction in their natural habitats, C. macropomum breeding units should be considered for the generation of fingerlings for both genetic improvement and conservation purposes (Lopera-Barrero et al., 2015; Ribeiro et al., 2016; Santos, Santana, Sá Leitão, Paula Silva, \& Almeida Val, 2016). However, it is necessary that the females and males breeders have high genetic variability to transfer to their progeny, since inbreeding depression can lead to a decrease in zootechnical characteristics of interest (Rodriguez-Rodriguez et al., 2013) fundamental to the success of genetic improvement programs, and adaptability, in the case of restocking natural populations.

One of the most common methods for this purpose is the analysis of genetic diversity and population structure through microsatellite markers (SSR-Simple sequence repeats), which is one of the most widespread tools used for the characterization 
of fish stocks (Lopera-Barrero et al., 2016; Santos et al., 2016; Souza et al., 2018a). Since they have a codominant inheritance pattern, show a high number of polymorphisms and generate a large amounts of informative data (Abdul-Muneer, 2014), SSRs allow the characterization of several genetic parameters that are useful for the management of fish stocks.

Microsatellite markers in the literature has been developed for the characterization of fish stocks. Tambaqui is the most produced native species in Brazil with a highest production rate at the northern region, so its genetic evaluation is extremely important to increase productivity in fish farming. Priorly, the literature does not take into consideration ancestral studies for the subsequent reproduction and maintenance of genetic diversity in fish populations (Brabo et al., 2016; Moraes et al., 2017; Peixe BR, 2020). The objective of this paper is to evaluate the genetic diversity of three broodstocks of $C$. macropomum from the State of Rondônia. In this context, one contribution of this work is to consider previous genetic studies in order to complement the genetic data of these breeding stocks.

\section{Materials and Methods}

The study was approved by the Committee of Ethics in the use of animals of the State University of Londrina (CEUA_UEL nº 18610.2016.00). Caudal fin samples (approximately $0.5 \mathrm{~cm}^{2}$ ) were randomly collected of males and females from three fish farms in the State of Rondônia, Brazil: 27 samples from Ji-Paraná - JP (10 53'07'S, 61 ${ }^{\circ}$ 56' 06”'W), 30 samples from Ouro Preto do Oeste OP ( $\left.10^{\circ} 44^{\prime} 53^{\prime} \mathrm{S}, 62^{\circ} 12^{\prime} 57^{\prime \prime} \mathrm{W}\right)$, and 32 samples

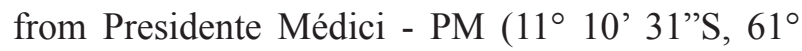
$\left.54^{\prime} 05^{\prime \prime} \mathrm{W}\right)$. These three fish farms consist of $C$. macropomum broodstock and have the purpose of distributing fingerlings to other fish farms. On the other hand, JP, PM and OP were previously analyzed by Ribeiro et al. (2016) implementing the RAPD technique (dominant molecular marker), proposing a new study using the co-dominant marker (SSR) to determine and validate the results.

DNA extraction was accomplished using a $\mathrm{NaCl}$ protocol performed according to the methodology described by (Lopera-Barrero et al., 2008). The DNA was quantified using a SLIPQ 026-Quantificador L-Quant spectrophotometer (Loccus Biotecnology, Ribeirão Preto, Brazil). Samples were diluted to $30 \mathrm{ng} / \mu \mathrm{L}$. DNA integrity was checked using $1 \%$ agarose gel electrophoresis, run at 100 volts for 60 minutes. The gel was visualized in a transilluminator with ultraviolet light and was photographed with a Kodak EDAS camera (1D Image Analysis 3.5 Kodak, USA).

PCR was performed in a final volume of $15 \mu \mathrm{l}$, with $1 \mathrm{X}$ Tris- $\mathrm{KCl}$ buffer, $2.0 \mathrm{mM}$ of $\mathrm{MgCl}_{2}, 0.8 \mu \mathrm{M}$ of the primers (Forward and Reverse), $0.2 \mathrm{mM}$ of dNTP, one Platinium Taq DNA Polymerase unit (Invitrogen $^{\circledR}$, Carlsbad, USA) and $60 \mu \mathrm{g}$ of DNA. For amplification, initially, DNA was denatured at $94^{\circ} \mathrm{C}$ for four minutes, subsequently followed by 30 cycles of 60 seconds of denaturation at $94^{\circ} \mathrm{C}, 60$ seconds of annealing and 60 seconds of extension at $72^{\circ} \mathrm{C}$. Cycling was followed by 10 minutes of a final extension at $72^{\circ} \mathrm{C}$. The amplified primers were: Cm1A8 (EU685306), Cm1A11 (EU685307), Cm1C8 (EU685308), Cm1D1 (EU685309), Cm1E3 (EU685310) and Cm1H8 (EU685315) (Santos, Hrbek, \& Farias, 2009). The recommended annealing temperatures for the primers as described by Santos et al. (2009) were used. PCR was performed on a Veriti ${ }^{\circledR}$ thermal cycler (Applied Biosystems $^{\circledR}$, Austin, TX, U.S.A.).

The amplified products were separated on $10 \%$ polyacrylamide gel (acrylamide: bis-acrylamide 29: 1), with electrophoresis conducted in TBE $0.5 \mathrm{X}$ buffer at 180 volts and 250 MA for eight hours. Subsequently, gel staining was performed with silver nitrate for visualization of the microsatellite alleles. The gels were photographed and analyzed using Adobe Photoshop CC (64 Bit) software. 
Photographs of the gels were aligned and allele sizes were calculated using a 100 bp DNA ladder (Invitrogen ${ }^{\circledR}$, Carlsbad, USA).

The number of alleles, expected $(\mathrm{He})$ and observed heterozygosity (Ho), Hardy-Weinberg equilibrium test (HWE), analysis of molecular variance - AMOVA and genetic differentiation $\left(\mathrm{F}_{\mathrm{ST}}\right)$ were estimated by the Arlequin 3.0 program (Excoffier, Laval, \& Schneider, 2005). Allele frequency, allelic richness (Ar) and the inbreeding coefficient $\left(\mathrm{F}_{\text {IS }}\right)$ were calculated using FSTAT 2.9.3.2 (Goudet, 2002). The effective number of alleles (Ae) was calculated for each locus using GenAlex version 6.5 software (Peakall \& Smouse, 2012). Gene flow (Nm) between stocks was calculated using the GENEPOP 4.0.6 program (Rousset, 2008). For differentiation of Fst values, the definition proposed by Wright (1978) was used, were values from 0.00 to $0.05,0.051$ to $0.15,0.151$ to 0.25 and $>0.25$ indicate small, moderate, high and very high genetic differentiation. A dendrogram based on the genetic distance defined by Nei (1978) was constructed with a UPGMA analysis using MEGA version 5.0 software (Tamura et al., 2011). The STRUCTURE v.2.3.3 software (Pritchard, Stephens, \& Donnelly, 2000) was used to verify the existence of possible groupings $(\mathrm{K})$ of genetically similar populations, following the mixed model of clusters with a length period of 250,000 followed by 1,000,000 repetitions of MCMC (Markov chain Monte Carlo), the software assumed mixed ancestry between the correlated populations with allelic frequencies. Estimates of $\mathrm{K}$ (number of clusters) were obtained from simulations performed with $\mathrm{K}$ ranging from one to five $(K=1-5)$, reproducing 20 runs for each hypothetical value of $\mathrm{K}$. The number of clusters was determined using the method proposed by Evanno, Regnaut and Goudet (2005) implemented on the Structure Harvester website (Earl \& vonHoldt, 2012).

\section{Results and Discussion}

The six microsatellite loci generated 37 alleles. The total number of alleles per locus ranged from five $(\mathrm{Cm} 1 \mathrm{C} 8, \mathrm{Cm} 1 \mathrm{E} 3$ and $\mathrm{Cm} 1 \mathrm{H} 8)$ to eight (Cm1A8), with sizes between 140 bp (Cm1A8) to 310 bp (Cm1E3). The number of alleles identified in loci $\mathrm{Cm} 1 \mathrm{~A} 11, \mathrm{Cm} 1 \mathrm{C} 8$ and $\mathrm{Cm} 1 \mathrm{H} 8$ was similar to that observed in two broodstocks investigated by Moraes et al. (2017). However, the six loci presented lower numbers of alleles than those found by Santos et al. (2009) in a wild population collected on the São Miguel Island, Pará, who obtained number of alleles between $7(\mathrm{Cm} 1 \mathrm{~A} 8)$ and 21 alleles $(\mathrm{Cm} 1 \mathrm{H} 8)$ for the same loci implemented in this study. On the other hand, J. D. P. Aguiar et al. (2018) found an average number of alleles between 2.83 and 8.58 in broodstocks of $C$. macropomum in different regions of Brazil. The differences in the number of alleles observed can be attributed to the structure of these populations in different regions and may additionally be due to the reproductive management adopted in the fish farm (JP, OP and PM), which can lead to the disappearance of alleles in cases of intentional selection during mating.

Exclusive alleles and low frequency alleles (alleles with frequency $<0.100$ ) were observed in all stocks. JP was the stock that presented the highest number of alleles for both parameters: six exclusive alleles and 11 low frequency alleles (Table 1). The low allele frequencies, which tend to increase intrapopulation genetic differentiation, can be caused due to confinement, genetic bottlenecks or founder effect, which can be provoked by selection during the reproductive processes within each stock. In addition, the high number of exclusive alleles characterized an interpopulation genetic distancing in the stocks, mainly in the JP stock. The presence of these alleles suggests a restricted gene flow and presence of genetic drift (Azevedo et al., 2013), possibly related to the limited number of breeders in the stocks and their physical isolation. 
Table 1

Number (N), allele size (bp), exclusive alleles and low frequency alleles observed in Colossoma macropomum stocks

\begin{tabular}{|c|c|c|c|c|c|c|}
\hline & $\mathrm{Cm} 1 \mathrm{~A} 8$ & Cm1A11 & $\mathrm{Cm} 1 \mathrm{C} 8$ & Cm1D1 & Cm1E3 & $\mathrm{Cm} 1 \mathrm{H} 8$ \\
\hline $\mathrm{N}$ & 8 & 7 & 5 & 7 & 5 & 5 \\
\hline $\mathrm{pb}$ & $140-215$ & $200-260$ & $225-260$ & $160-230$ & $280-310$ & $256-282$ \\
\hline \multicolumn{7}{|c|}{ Exclusive alleles ${ }^{(\text {Frequency })}$} \\
\hline JP & $\begin{array}{l}200^{(0.111)} \\
215^{(0.148)}\end{array}$ & - & $231^{(0.038)}$ & - & $\begin{array}{l}305^{(0.093)} \\
310^{(0.014)}\end{array}$ & $282^{(0.019)}$ \\
\hline $\mathrm{OP}$ & $180^{(0.033)}$ & $200^{(0.017)}$ & - & - & - & - \\
\hline PM & $174^{(0.016)}$ & - & $260^{(0.097)}$ & $160^{(0.281)}$ & - & - \\
\hline \multicolumn{7}{|c|}{ Low frequency alleles ${ }^{\text {(Frequency) }}$} \\
\hline JP & $\begin{array}{l}140^{(0.074)} \\
150^{(0.074)}\end{array}$ & $\begin{array}{l}230^{(0.038)} \\
237^{(0.96)} \\
260^{(0.077)}\end{array}$ & $\begin{array}{l}225^{(0.038)} \\
231^{(0.019)}\end{array}$ & $200^{(0.074)}$ & $310^{(0.050)}$ & $\begin{array}{l}275^{(0.053)} \\
282^{(0.079)}\end{array}$ \\
\hline $\mathrm{OP}$ & $180^{(0.033)}$ & $\begin{array}{l}200^{(0.017)} \\
232^{(0.033)} \\
237^{(0.067)} \\
260^{(0.017)}\end{array}$ & - & $\begin{array}{l}182^{(0.067)} \\
200^{(0.067)} \\
230^{(0.017)}\end{array}$ & $300^{(0.043)}$ & $262^{(0.067)}$ \\
\hline PM & $174^{(0.016)}$ & - & $260^{(0.097)}$ & - & $300^{(0.093)}$ & $275^{(0.097)}$ \\
\hline
\end{tabular}

JP: Ji-Paraná, OP: Ouro Preto, PM: Presidente Médici

$<0.100$ low frequency alleles.

When analyzed individually, significant deviation $(\mathrm{p}<0.05)$ from the Hardy-Weinberg equilibrium was found for most loci $(\mathrm{Cm} 1 \mathrm{~A} 8$, Cm1C8, Cm1D1, Cm1E3 and Cm1H8 in JP; Cm1A8, Cm1D1, Cm1E3 and Cm1H8 in OP; and $\mathrm{Cm} 1 \mathrm{E} 3$ and $\mathrm{Cm} 1 \mathrm{H} 8$ in PM). According to Waples (2015), deviation from the Hardy-Weinberg equilibrium occurs due to forces such as selection, genetic drift, mutation or migration, all of which tend to change allele frequencies over time. In the case of finite and small populations, as found in fish farms, it is likely that a non-random selection of breeders and genetic drift are the main forces acting on the allele frequencies, corroborating the presence of exclusive and low frequency alleles found in the three broodstocks. The low values of effective alleles (Ae) in relation to allelic richness (Ar) reinforce the existence of several alleles segregating at low frequency (Table 2).

The average values of expected heterozygosity (He) were higher than those of the observed heterozygosity (Ho) for all stocks, which resulted in a significant $(\mathrm{P}<0.05)$ positive mean $\mathrm{F}_{\text {IS }}$ (Table 2), demonstrating a heterozygote deficit. In a study with C. macropomum broodstocks in Brazil, Santos et al. (2016) found He ranging from 0.48 to 0.63 and Ho from 0.26 to 0.52 , which demonstrated a heterozygote deficit shown by the $\mathrm{F}_{\mathrm{IS}}$. Moraes et al. (2017) also found values of this coefficient from 0.229 to 0.348 in two broodstocks in the Northern region. It is expected that in stocks kept in captivity, there will be a decrease in genetic diversity as a consequence of intentional selection and of the mating among parental (Jacometo et al., 2010; Lopera-Barrero et al., 2015; Santos et al., 2016). Also, founder effect, caused by a small number of individuals in the base population, can be a driving factor in the loss of genetic diversity in fish farms for altering allele frequencies through genetic drift (Santos et al., 2016; Moraes et al., 2017). Therefore, it is possible that the broodstocks analyzed in the present study have reduced genetic diversity due 
to the presence of this founder effect, which can be supported by the deficiency of heterozygotes in most loci, and consequently the deviation from HW equilibrium, and the significant positive $\mathrm{F}_{\mathrm{IS}}$, indicating the occurrence of inbreeding. Reproductive management aiming to maximize the use of breeders in mating, in order to avoid reproductive dominance of certain animals, whether male or female, can be strategies used to minimize the effects of drift and assist in the conservation of the genetic diversity of the broodstock (Souza et al., 2018b).

Table 2

Number of alleles per locus (Na), allelic richness (Ar), effective alleles (Ae), observed (Ho) and expected

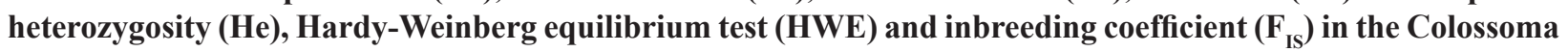
macropomum stocks

\begin{tabular}{cccccccc}
\hline Stocks & Locus & $\mathrm{Na}$ & $\mathrm{Ra}$ & $\mathrm{Ae}$ & $\mathrm{Ho}$ & $\mathrm{He}$ & $\mathrm{F}_{\text {IS }}$ \\
\hline \multirow{5}{*}{ JP } & Cm1A8 & 6 & 6 & 4.528 & 1.000 & $0.793^{*}$ & -0.266 \\
& Cm1A11 & 6 & 6 & 3.808 & 0.615 & 0.751 & 0.185 \\
& Cm1C8 & 4 & 4 & 2.220 & 0.230 & $0.560^{*}$ & 0.593 \\
& Cm1D1 & 5 & 5 & 3.710 & 0.740 & $0.744^{*}$ & 0.005 \\
& Cm1E3 & 4 & 4 & 3.265 & 0.200 & $0.711^{*}$ & 0.724 \\
& Cm 1H8 & 4 & 4 & 2.481 & 0.210 & $0.613^{*}$ & 0.663 \\
OP & Mean & 5 & 5 & 3.335 & 0.499 & 0.695 & $0.287^{*}$ \\
\hline \multirow{4}{*}{ Cm1A8 } & 4 & 4 & 2.675 & 1.000 & $0.636^{*}$ & -0.586 \\
& Cm1A11 & 7 & 6 & 3.614 & 0.733 & 0.735 & 0.003 \\
& Cm1C8 & 3 & 3 & 2.675 & 0.533 & 0.636 & 0.165 \\
& Cm1D1 & 6 & 6 & 2.699 & 0.466 & $0.640^{*}$ & 0.274 \\
& Cm1E3 & 3 & 3 & 2.159 & 0.000 & $0.548^{*}$ & 1.000 \\
Pm 1H8 & 4 & 4 & 2.620 & 0.233 & $0.628^{*}$ & 0.633 \\
& Mean & 5 & 4 & 2.740 & 0.494 & 0.637 & $0.228^{*}$ \\
\hline \multirow{3}{*}{ Pm1A8 } & 3 & 3 & 2.022 & 0.500 & 0.513 & 0.026 \\
& Cm1A11 & 2 & 2 & 1.992 & 0.500 & 0.505 & 0.012 \\
& Cm1C8 & 3 & 3 & 2.385 & 0.451 & 0.590 & 0.238 \\
& Cm1D1 & 3 & 3 & 2.589 & 0.562 & 0.623 & 0.099 \\
& Cm1E3 & 3 & 3 & 2.378 & 0.185 & $0.590^{*}$ & 0.690 \\
& Cm 1H8 & 4 & 4 & 3.070 & 0.225 & $0.685^{*}$ & 0.674 \\
& Mean & 3 & 3 & 2.406 & 0.404 & 0.584 & $0.313^{*}$ \\
\hline
\end{tabular}

$\mathrm{He}^{*}$ significance found in the Hardy-Weinberg equilibrium test at the 0.05 level.

JP: Ji-Paraná; OP: Ouro Preto do Oeste; PM: Presidente Médici $\mathrm{F}_{\mathrm{IS}} *: \mathrm{P}<0.05$.

The AMOVA showed greater variation are within stocks than the between them $(p<0.05)$. Genetic differentiation $\left(\mathrm{F}_{\mathrm{ST}}\right)$, according to the classification defined by Wright (1978), indicates a significant moderate differentiation between the three stocks
(Table 3). Low gene flow (Nm) was identified between the stocks, which was smaller between JP x PM (0.256), followed by OP x PM (0.316), and larger between JP x OP (0.341). The dendrogram showed the formation of two groupings: one 
comprised of the $\mathrm{OP}$ and $\mathrm{PM}$ populations and the other containing the JP individuals (Figure 1). Bayesian analysis performed with Structure software revealed $\mathrm{K}=3$ groupings (Figure 2), and the cluster arrangements corroborated the groupings produced in the dendrogram, these figures (Figure 1 and Figure 2) are new results obtained based in the co-dominant technique applied in these population.

Table 3

Analysis of molecular variance (AMOVA) and genetic differentiation $\left(\mathrm{F}_{\mathrm{ST}}\right)$, using the classification defined by Wright (Wr), of Colossoma macropomum stocks

\begin{tabular}{lccccc}
\hline \multicolumn{1}{c}{ Variation Source } & $\begin{array}{c}\text { Sum of } \\
\text { squares }\end{array}$ & $\begin{array}{c}\text { Variance } \\
\text { Components }\end{array}$ & $\begin{array}{c}\text { Percentage of } \\
\text { variation }\end{array}$ & $\mathrm{F}_{\text {ST }}$ & Wr \\
\hline Between the stocks & 20.086 & 0.147 & $10.48^{*}$ & & Moder- \\
Between individuals Within the stocks & 112.819 & 0.520 & 3.69 & 0.105 & ate \\
Within the individuals & 107.500 & 1.208 & 85.82 & & \\
\hline
\end{tabular}

$* \mathrm{P}<0.05$.

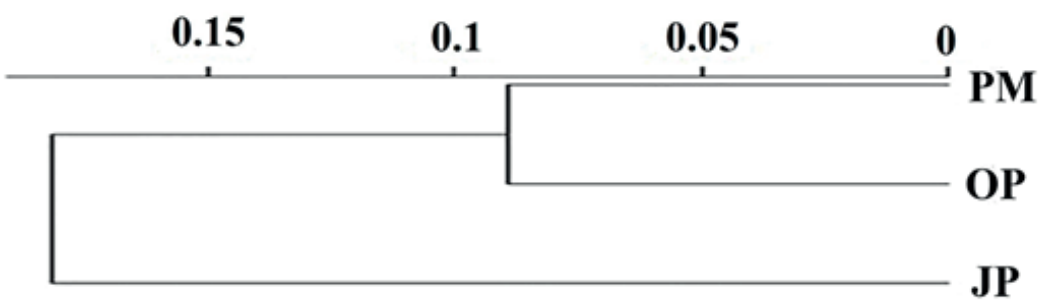

Figure 1. Dendrogram results for the three broodstock of Colossoma macropomum based on 6 microsatellite markers. JP: Ji-Paraná; OP: Ouro Preto do Oeste; PM: Presidente Médici.

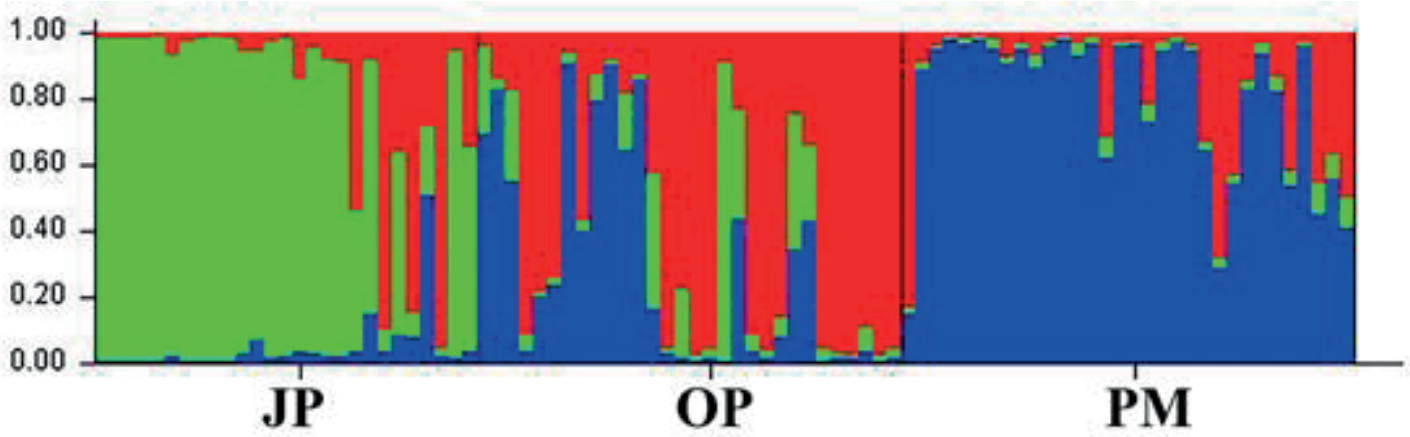

Figure 2. Bayesian cluster analysis $(\mathrm{K}=3)$ of the 6 microsatellite loci in the three broodstock of Colossoma macropomum, run in the Structure program. JP: Ji-Paraná; OP: Ouro Preto do Oeste; PM: Presidente Médici. 
The characterization of the genetic diversity in captive stocks should be a priority for the development of strategies to reduce genetic erosion and minimize the risk of inbreeding depression (J. Aguiar et al., 2013). Our results indicated the presence of moderate genetic diversity in the studied broodstocks; however, they warn of a possible decline in the diversity of the upcoming generations. For this reason, incorporation of new breeders is recommended (Souza et al., 2018a) in order to neutralize the effects of genetic drift and to improve genetic diversity indexes. As emphasized by Santos et al. (2016), an apparent solution would be to increase the gene flow between stocks and natural populations or that between other $C$. macropomum stocks, being careful to base the incorporation of gene flow on genetic analysis. This could increase the genetic variability of isolated broodstocks, as in the present case, through the incorporation of new genetic material. Furthermore, knowing that the selection of breeders with better phenotypic characteristics is common and sometimes unavoidable for reproductive units, constant genetic monitoring could help in the implementation of measures that could keep the rate of inbreeding under control.

Future studies should be conducted in order to evaluate whether the present inbreeding is affecting zootechnical parameters such as growth rate and fertility in these stocks. The data generated will help in making decisions regarding the management of fish farm activities, since elucidation of the genetic relationships between breeders will allow for better control of mating with the incorporation of new breeders.

\section{Conclusion}

Moderate genetic diversity is present within the studied stocks; however, a high heterozygote deficit evidenced by the $\mathrm{F}_{\mathrm{IS}}$ coefficients was found. Moderate genetic differentiation $\left(\mathrm{F}_{\mathrm{ST}}\right)$ was been found between broodstocks. The incorporation of new breeders based on genetic analysis is recommended in order to increase gene flow within broodstocks and to reduce the rate of inbreeding.

\section{Acknowledgments}

The authors would like to thank the "Conselho Nacional de Desenvolvimento Científico e Tecnológico (CNPq)", the "Coordenação de Aperfeiçoamento de Pessoal de Nível Superior" (CAPES), and the "Programa de Pós Graduação em Ciência Animal (Universidade Estadual de Londrina)" for scholarships and financial support.

\section{References}

Abdul-Muneer, P. M. (2014). Application of microsatellite markers in conservation genetics and fisheries management: recent advances in population structure analysis and conservation strategies. Genetic Research International, 2014, 691-759. doi: $10.1155 / 2014 / 691759$

Aguiar, J., Schneider, H., Gomes, F., Carneiro, J., Santos, S., Rodrigues, L. R., \& Sampaio, I. (2013). Genetic variation in native and farmed populations of Tambaqui (Colossoma macropomum) in the Brazilian Amazon: Regional discrepancies in farming systems. Anais da Academia Brasileira de Ciências, 85(4), 1439-1447. doi: 10.1590/0001376520130007

Aguiar, J. D. P., Gomes, P. F. F., Hamoy, I. G., Santos, S. E. B. D., Schneider, H., \& Sampaio, I. (2018). Loss of genetic variability in the captive stocks of tambaqui, Colossoma macropomum (Cuvier, 1818), at breeding centres in Brazil, and their divergence from wild populations. Aquaculture Research, 49(5), 1914-1925. doi: 10.1111/are. 13647

Araujo-Lima, C. R. M. \& Goulding, M. (1997). So fruitful fish: ecology, conservation, and aquaculture of the Amazon's Tambaqui. New York: Columbia University Press, 1997.

Azevedo, R. M. D., Santos, H. O. D., Ferreira, R. A., Marçal, R. M., \& Silva-Mann, R. (2013). Variabilidade genética em populações de Erythrina velutina Willd. por meio de isoenzimas. Revista Acadêmica: Ciências Agrárias e Ambientais, 11(1), 43-51. doi: 10.7213/academica.10.S01.AO05 
Brabo, M. F., Fernando, L., Pereira, S., Abreu, D., Campelo, V., \& Veras, G. C. (2016). Cenário atual da produção de pescado no mundo, no Brasil e no estado do Pará: ênfase na aquicultura. Acta of Fisheries and Aquatic Resources, 4(2), 50-58. doi: 10.2312/Actafish.2016.4.2.50-58

Costa, J., Freitas, R., Gomes, A. L., Carneiro, D., \& Martins, M. I. (2016). Effect of stocking density on economic performance for Colossoma macropomum (Cuvier, 1816), juvenile in earthen ponds. Latin American Journal of Aquatic Research, 44(1), 165170. doi: 10.3856/vol44-issue1-fulltext-18

Earl, D. A. \& vonHoldt, B. M. (2012). STRUCTURE HARVESTER: a website and program for visualizing STRUCTURE output and implementing the Evanno method. Conservation Genetics Resources, 4(2), 359-361. doi: 10.1007/s12686-011-9548-7

Evanno, G., Regnaut, S., \& Goudet, J. (2005). Detecting the number of clusters of individuals using the software STRUCTURE: a simulation study. Molecular Ecology, 14(8), 2611-2620. doi: 10.1111/j.1365-294X.2005.02553.x

Excoffier, L., Laval, G., \& Schneider, S. (2005). Arlequin ver. 3.0: an integrated software package for population genetics data analysis. Evolutionary Bioinformatics, 1(1), 47-50.

Food and Agriculture Organization (2020). The state of world fisheries and aquaculture 2020. Sustainability in action. Rome: FAO.

Goudet, J. (2002). FSTAT: a program to estimate and test gene diversities and fixation indices (version 2.9.3.2). Lausanne: University of Lausanne, Department of Ecology \& Evolution; 2002. Retrieved from http:// www2.unil.ch/popgen/softwares/fstat.htm

Jacometo, C. B., Lopera-Barrero, N. M., RodriguezRodriguez, M. D. P., Gomes, P. C., Povh, J. A., Streit Jr, D. P.,... Ribeiro, R. P. (2010). Variabilidade genética em tambaquis (Teleostei: Characidae) de diferentes regiões do Brasil. Pesquisa Agropecuária Brasileira, 45(5), 481-487. doi: 10.1590/S0100204X2010000500007

Lopera-Barrero, N. M., Povh, J. A., Ribeiro, R. P., Gomes, P. C., Jacometo, C. B., \& Silva, T. L. (2008). Comparison of DNA extraction protocols of fish fin and larvae samples: modified salt $(\mathrm{NaCl})$ extraction. Ciencia e Investigación Agrarria, 35(1), 65-74. doi: 10.4067/S0718-16202008000100008

Lopera-Barrero, N. M., Rodriguez-Rodriguez, M. P., Fornari, D. C., Resende, E. K., Poveda-Parra, A. R., Braccini, G.,... Ribeiro, R. P. (2015). Genetic variability of broodstocks of Tambaqui (TeleosteiCharacidae) from the northeast region of Brazil. Semina: Ciências Agrárias, 36(6), 4013-4021. doi: 10. 5433/1679-0359.2015v36n6p4013

Lopera-Barrero, N. M., Santos, S. C. A., Goes, E. S. R., Castro, P. L., Souza, F. P., Poveda-Parra, A. R.,... Ribeiro, R. P. (2016). Monitoramento e conservação genética de populações naturais de Prochilodus lineatus dos rios Pardo, Mogi-Guaçu e Tietê, São Paulo. Arquivo Brasileiro de Medicina Veterinária e Zootecnia, 68(6), 1621-1628. doi: 10.1590/16784162-8791

Moraes, A. Neto, Ayres, D. R., Streit, D. P. Jr.,.LoperaBarrero, N. M., Ferraz, P. B., F ${ }^{\circ}$, Corrêa, R. A. C., F ${ }^{\circ}, \ldots$ Povh, J. A. (2017). Genetic diversity of tambaqui broodstocks in stock enhancement programs. Semina: Ciências Agrárias, 38(3), 16551659. doi: 10.5433/1679-0359.2017v38n3p1665

Nei, M. (1978). Estimation of average heterozygosity and genetic distance from a small number of individuals. Genetics, 89(3), 583-590.

Peakall, R., \& Smouse, P. E. (2012). GenALEx 6.5: Genetic analysis in Excel. Population genetic software for teaching and research-an update. Bioinformatics, 28(19), 2537-2539. doi: 10.1093/ bioinformatics/ bts460

Peixe Br (2020). Anuário Peixe Br da Piscicultura. Recuperado de https://www.peixebr.com.br/ anuario-2020/

Pritchard, J. K., Stephens, M., \& Donnelly, P. (2000). Inference of population structure using multilocus genotype data. Genetics, 155.(2), 945-959.

Ribeiro, R. P., Rodriguez-Rodriguez, M. P., Resende, E. K., Souza, F. P., Povh, J. A., Poveda-Parra, A. R.,... Lopera-Barrero, N. M. (2016). Genetic characteristics of Tambaqui broodstocks in the state of Rondônia, Brazil: implications on production and conservation. Semina: Ciências Agrárias, 37(4, Supl. 1), 2375-2386. doi: 10.5433/1679-0359.2016v37n4Supl1p2375

Rodriguez-Rodriguez, M. P., Lopera-Barrero, N. M., Vargas, L., Albuquerque, D. M., Goes, E. S. D. R., Prado, O. P. P. D., \& Ribeiro, R. P. (2013). Caracterização genética de gerações de tilápia Gift por meio de marcadores microssatélites. Pesquisa Agropecuária Brasileira, 48(10), 1385-1393. doi: 10.1590/S0 100-204X2013001000010

Rousset, F. S. (2008). GENEPOP' 007: a complete reimplementation of the GENEPOP software for Windows and Linux. Molecular Ecology Research, 8(1), 103-106. doi: 10.1111/j.1471-8286.2007.019 31.X 
Santos, C. H. A., Santana, G. X., Sá Leitão, C. S., Paula Silva, M. N., \& Almeida Val, V. M. F. (2016). Loss of genetic diversity in farmed populations of Colossoma macropomum estimated by microsatellites. Animal Genetics, 47(3), 373-376. doi: 10.1111/age.12422

Santos, M. D. C. F., Hrbek, T., \& Farias, I. P. (2009). Microsatellite markers for the tambaqui (Colossoma macropomum, Serrasalmidae, Characiformes), an economically important keystone species of the Amazon River floodplain. Molecular Ecology Resources, 9(3), 874-876. doi: 10.1111/j.1755-0998. 2008.02331.x

Souza, F. P. de, Castro, P. L. D., Goes, E. S. D. R., Ribeiro, R. P., Santos, S. C. A. D., Lima, E. C. S. D., Murari, P. J. F., \& Lopera-Barrero, N. M. (2018a). Genetic variability of Prochilodus lineatus in artificial and semi-natural reproduction. Italian Journal of Animal Science, 17(2), 321-325. doi: 10. 1080/1828051X.2017.1365312
Souza, F. P. de, Lima, E. C. S., Castro, P. L., Goes, E. S. R., Ribeiro, R. P., \& Lopera-Barrero, N. M. (2018b). Contribuição parental em progênies de Curimba usando diferentes sistemas reprodutivos. Boletim do Instituto de Pesca, 44(1), 74-79. doi: 10.20950/16782305.2018.276

Tamura, K., Peterson, D., Peterson, N., Stecher, G., Nei, M., \& Kumar, S. (2011). MEGA5: molecular evolutionary genetics analysis using maximum likelihood, evolutionary distance, and maximum parsimony methods research resource. Molecular Biology Evolution, 28(10), 2731-2739. doi: 10.1093/ molbev/msr121

Waples, R. S. (2015). Testing for Hardy-Weinberg proportions: have we lost the plot? Journal of Heredity, 106(1), 1-19. doi: 10.1093/jhered/esu062

Wright, S. (1978). Evolution and genetics of populations. Variability within and among natural populations ( $\mathrm{p}$. 590, v. 4). Chicago: University of Chicago. 